\title{
Historical Overview on Decentralization and local Government of Albania
}

\author{
Enea Sherifi \\ PhD Candidate, Institute of European Studies, University of Tirana
}

\section{Doi:10.5901/ajis.2016.v5n2p227}

\begin{abstract}
Even before the announcement of Autonomy of Albania from the Ottoman Empire, Albanians attempted institutional organization. The Albanian Pashaliks marked the beginning of a new period. Provisional Government of Ymer Prizreni was established institutionally and is considered the first step of decentralized nature of the governance Albanian lands. With the "Liberation of Skopje" in the beginning of August 1912, the Foreign Minister of Austria-Hungary Leopold Berthtold, on August 13,1912 , proposed to the Great Powers a project for the gradual decentralization policy of the Ottoman Empire. Newspapers of the time considered the trend of administrative decentralization as a stepladder of political decentralization. The Government of Ismail Qemali made an administrative territorial reorganization in August 1913. On November 23, 1913, "The Canon of Civil Administration of Albania" was established. Organic Statute of Albania, with Articles 95-97, shared Albania on 7 Sanjaks with kazas and provinces just as in the Ottoman Empire. In 1992 Albania had 12 prefectures, 36 districts and 357 communes and municipalities. Today, with the changes following the new territorial reform, Albania has only 61 municipalities and 12 counties and no commune. Actually, local government is not administered by municipalities, communes and counties but only by municipalities. This has caused the need for these changes in authorities and competences to be reflected in the Constitution as well, through appropriate amendments.
\end{abstract}

Keywords: decentralization, local government, local autonomy, administrative reform, cantons.

\section{Introduction}

Albania spent several centuries under Ottoman rule and local governments was done by the Ottomans. Even before the announcement of Autonomy of Albania from the Ottoman Empire, Albanians attempted the institutional organization. Pashalik of Shkodra and the Pashalik of loannina, in the institutional perspective, are a successful attempt to revive the administrative and institutional continuity of New Epirus and Old Epirus, the Middle Ages. Ascertaining bears the value of the historical truth, because it is supported by the letter of Ali Pasha addressed to the Russians, with the political project, for separation from the Ottoman Empire and the creation of the hereditary monarchy. (Irakli Koçollari 2013, pg 160-167). The letter of Ali Pasha's addressed to Meternik Chancellor on March 3, 1820, sheds light on the political project, with the subject of assisting him to draft a constitution that would serve Ali Pasha of Tepelena as the legal basis for declaring autonomy from the Ottoman Empire. This request can be considered as the first act of decentralized nature, for selfgovernment (K.von Meternik, 1881, pg 535). The organization attempts continued after the assassination of Ali Pasha as well. The document of Ismail Vlora, the grandfather of Ismail Qemali on November 29, 1828, should be assessed as a historical fact that the Pashalik of Ali Pasha was an institution that preceded the institutional processes, like the Greeks and Serbs for independence. Ismail Bey Vlora, proposed to the Albanian leaders in Southern Albania, not to be involved in the Greek insurgency, as they were ordered by the Sublime Porte, but to meet in Berat and discuss about the Albanian future, like free sons of Albania. (Dritan Egro, 2010, pg12 ) With the League of Prizren, the Albanian nationalism got national and institutional character. League was treated in Kahrarname as a political institution which was independent from the Sublime Porte. In its 14th Article stated that the Istanbul Government will not interfere in the League's affairs (A.SH 2002, pg 145). The League canon was adopted on July 2, 1878 after being cleared by the terms of Islamic character. Istanbul committee chaired by Abdul Frasher decided to ask the Sublime Porte, the formation of the Albanian Vilayet. This decision was published on September 27, 1878, in the journal "Terxhuman-i-Shark" published in Istanbul, under the direction of Sami Frasher (A.SH 2002, pg 172). League assumed some prerogatives in the judicial area. On May 12, 1879, at the request of Zija Prishtina, who was a member of the Committee of Istanbul, the Sultan, allowed the creation of the Albanian courts, as alternative courts with the Ottoman ones. On August 3, 1880, the center of Vilayet of Kosovo, announced the authorities in Istanbul, that the League of Prizren, through its representative Ali Aga, and fifteen of his entourage, communicated to them the decision of the League for the abolition of the court of first instance in the sub prefecture of Pristina. Whereas in Gjakova and Peja people demanded that the Turkish courts to be closed (A.SH, 
1978, p 100). Extraordinary Assembly of Prizren, in January 1881, turned the National Committee in League's interim government, with its president Ymer Prizren (Nuray Bozbora, 2002, pg 181). Provisional Government of Ymer Prizren was established institutionally and can be considered as the first step of decentralized nature of governance in the Albanian lands. This political and instituconal reality is described in the letter of Sami Frasher addressed to Jeronim De Rada in February 1881. According to Sami Frasher, "The Albanian League took the name of the used Government with the authority in the Kosovo Vilayet" (A.SH, 2002, pg 220). With the announcement of Hyrjetit, 1908, the revitalizing cycle of Albanian National Movement has been resumed, with the Assemblies of Dibra, Bitola, and Parliament of Gërçe in 1911 as well as the meeting of Junik in June 1912, led by Hasan bey Prishtina. With the "Liberation of Skopje" in the beginning of August 1912, the Foreign Minister of Austro-Hungary Leopold Berthtold, on August 13, 1912, proposed to the Great Powers a project for the gradual decentralization policy of the Ottoman Empire (AlH, No. 12087, dated 15 August 1912) This act forced the Porte to accept the demands of the Albanian National Movement which, after the League of Prizren, marked the governance of many cities by Albanians. Newspapers of the time considered the trend of administrative decentralization as a stepladder of political decentralization (AlH, No 72, 1912). The meeting of Hasan Prishtina, as a representative of the Albanian National Movement, with the commission of the Ottoman Empire, represented by Marshal Ibrahim Pasha, on August 18, 1912, for the acceptance of the Memorandum of Ferizaj, was associated with the termination of the Ottoman government in many cities, where Albanian Councils started to operate (Ramiz Abdyli, 2004, pg 408). Mytesarif Mehmet Pasha Dralla was appointed in Prizren, Nexhip Draga established the committee for replacement of the Ottoman officials in Skopje. The same situation occurred in the majority of Albanian cities where two powers existed. Albanian committee or council was led by Zejnullah Bey in Vushtri / Vuçiterna, by Idriz Seferi in Gjilan, by Riza Bey in Gjakova, etc. The government was called "Albanian Popular Bodies". "Drita" Newspaper of the Monastery wrote that all public authorities in Mitrovica, in Novi Pazar and in the cities around, were led by Isa Boletini. (Drita No. 98, 1912)

\section{Metodology}

The data have been analyzed for the confirmation of the hypothesis through the variables obtained in archival sources, in historical studies and legislation on decentralization of the local government. Comparative and narrative addressing truthfully reflects the reality, evolution and difference with the most advanced standards.

\section{The Morphology of Local Government in Albania 1912 - 1944}

Following the declaration of independence on November 28, 1912, the Assembly of Vlora chose the interim government of Ismail Qemali, which informed the prefectures about this on December 4, 1912 (Aqsha, P. 245). Although his government was not recognized by the Great Powers, the Government of Vlora spread its authority in a very limited territory, which included Elbasan, Berat, Fier, Vlora and Mallakastra with a population of around 250-300 thousand inhabitants. In these areas the government appointed several prefects. Aqif Pasha continued his office in Elbasan, Nexhip Bashai from Peja was appointed in Vlora, the former mytesarif Ali Riza Koka was fired in Berat and Fejzi Alizoti was appointed. (AlH, Vj. 23-27-2786). Following the resignation of the Minister Mithat Frashëri in March 1912, Myfit Libohova also resigned on July 25,1913 , but encouraged by Italy he withdrew it, with the aim of fighting the government from inside. (A. PA.,Vj. 23-27-2792). To improve the image and increase control over the territoryin the north and south, the government attempted to make an administrative and territorial reorganization in August 1913, declaring the kaza of Vlora a Sanjak and appointed the former mytesarif of Gjirokastra, Fehim bay Leskovik, the prefect, earning the amount of 1000 francs per month. The government also discussed that Tepelena and Kurvelesh join the Sanjak of Vlora. At the same time Kaza of Mallakaster was established, with boundaries between Vjosa river and Seman river, based in Selisht. Ismail Qemali appointed his loyal one, Ahmet Durmishi form Vlora, a deputy prefect (Kajmekam), with a monthly salary of 500 francs. It was discussed of establishing Kaza of Fier as well. Kaza of Berat, Skrapar of Lushnja left unestablished. Mehdi Frashëri was appointed prefect of Berat. Following the departure of the Greek forces in the south, the Sanjak of Korca and Gjirokastra would be reorganized. While Përmeti and Leskoviku would create a separate Sanjak and the seat of Sanjak of Gjirokastra would be in Saranda, as a counterweight to Corfu. Ismail Qemali proposed the establishment of Sanjak in the region of Lumë, in the Highlands of Gjakova and Dukagjin, as well as in Mirdita. Esat Toptani appointed Ahmet Zogu as mytesarif in Mat. (A.PA., Vj. 23-27-2795). Ismail Qemali felt the lack of breathing in his government since the opposition bloc driven by the international factor was reacting more explicitly than before against him. Although the political pressure was growing, inspired by democratic principles for the organization of the state, on November 23, 1913, 
he decreed the act that was named "Canon of the the Civil Administration in Albania" (Aleks Luarasi, 1999, pg 18). The basic principle on which the morphology of local government would rely was the "centralization of authority in vertical line". Ismail Qemali showed the idea of regional organization based on the Swiss model, by naming the local units as "cantons". This view was not accepted because it would deepen the disunity and the independence of leading could become a source of intrigue. The government decided that the country was divided into 10 prefectures, headed by prefects. Administrative Council would be near the prefect, which limited his power. Subprefecture would be an executive subunit, headed by deputy prefect, and below it the province was accepted, headed by the head of the province (in Albanian named "krahinari"). Administrative Council of the prefecture as a consultative body had the General Council, which consisted of members of the administrative council, and $25 \%$ of the members would be elected by the people (Alex LUARASI, 1999, p 20). The canon of civil administration is the first law of democratic spirit for local government. With the law on the administrative organization of Albania the administrative division of the Empire, including Sanjak and mytesarif, kaza and kajmekam had been terminated and, prefectures, sub-prefectures and provinces were established (Alex LUARASI, 1999, p.28). Conference of Ambassadors on July 29, 1913 defined the political status of Albania. The Prince commenced the state activity when International Commission of Control had not yet completed the project on organizing branches of the Albanian administration. Organic Statute of Albania would serve to establish the political institutions of the Principality of Albania. Pursuant to Article 6 of the Final Decision of the Conference of Ambassadors in London, the draft statute should have been completed within January 1914. Prince Wilhelm von Wied came to Albania on March 7, 1914 and started to exercise his state activity without constitutional legal norms. Pursuant to Articles 4,6,7 and 8 of the Decision of the Conference of Ambassadors in London, the functions of institutions of the Principality of Albania were performed by ICC (Alex LUARASI, 1999, p 30 ). Organic Statute of Albania was commited by ICC. Meh'di Frashëri, the Albanian delegate in ICC opposed the project with political and legal logic (British Documents .., V.II, f.366-369). Organic Statute of Albania ended on April 15, 1914 in Vlora. It was signed by members of ICC. The statute consisted of 7 chapters and 216 articles. Pursuant to Articles 95-97, Albania was divided into 7 Sanjaks with Kazas and provinces, just like in the Ottoman Empire (British Documents no.54, f.347-366). Congress of Lushnja held the previous administrative organization until 1924. The government established changed the name of the local government and the country was divided in 8 prefectures. The local division was done under the Organic Law of the Municipality, approved on November 26, 1921. According to law, the city with over 250 families may be proclaimed municipality. In 1924, Berat, Dibra, Durres, Elbasan, Gjirokastra, Korca, Shkodra and Vlora were prefectures. There were 39 subprefectures. Tirana was a separate subprefecture. With the declaration of the Republic on January 21, 1925 the administrative-territorial organization changed and the country was divided into 10 prefectures, in subprefectures and communes or provinces (districts) and municipalities in urban areas. In 1926 Albania had the following Prefectures: Prefecture of Berat, with 5 sub-prefectures: Berat, Fier, Lushnjë, Mallakastra and Skrapar and 5 provinces (districts): Cakrani, Libofsha, Roskoveci, Semani and Tomorica, with 531 villages with a population of 11.6223 inhabitants and with an area of $3933.2 \mathrm{~km}^{2}$. Prefecture of Dibra with three subprefectures: Dibra, Mat, Zerqani, 11 provinces (districts): Arrasi, Golloborda, Gryka, Homeshi, Kthella, Luznia, Lura, Maqellara, Reç-Dardhë, Strajca and Trojka, with 201 villages with a population of 83,006 inhabitants and with area of $2386.1 \mathrm{~km}^{2}$. Prefecture of Durrës, with 4 sub-prefectures: Durrës, Kavaja, Kruja and Shijak, with 4 provinces (districts): Ishm, Milot, Ndroq and Prezë, and 137 villages with a population of 57.874 inhabitants and with an area of $1.596 \mathrm{~km}^{2}$. Prefecture of Elbasan, with the following subprefectures: Elbasan, Gramsh and Peqin and the following provinces (districts): Çermenikë, Librazhd, Mollas, Qukës and Shënepremte, and with 312 villages and a population of 81.228 inhabitants and with area of $2.955 \mathrm{~km}^{2}$. Prefecture of Gjirokastër, Prefecture of Korçë, Prefecture of Kosovo IKukës-A.B, Prefecture of Shkodër, Prefecture of Vlorë, Prefecture of Tirana. With the approval of the Kingdom's new statute, on September 1, 1928 administrative-territorial organization had no significant change. Legal basis for this new local morphology became Article 13 of the Law "On the implementation of the Civil Code", which entered into force on February 15, 1929. According to administrative organization in 1934, the country was divided into 10 prefectures, 30 subprefectures, 160 communes and 2.551 settlements. By this division "the province" was abolished and "the commune" joined. In the organization of 1937 the vertical pyramid was maintained, but the term "district", "commune" and "municipality" was used in the names. This administrative organization was used up to the Italian fascist occupation, which in 1940 made a new administrative division, with 10 prefectures divided into 30 subprefectures. These units were divided into 159 smaller local units with 23 municipalities, 136 communes and 2551 settlements. In May 1940 the administrative-territorial division was as follows: Prefecture of Berat, Prefecture of Dibër, Prefecture of Durrës, Prefecture of Elbasan, Prefecture of Gjirokastër, Prefecture of Korçë, Prefecture of Kosovo, Prefecture of Shkodër, Prefecture of Vlorë and Prefecture of Tirana. 


\section{The Functions of the Local Government Units in 1925-1945}

The unit "municipality", was established after 1928 in the civil settlements with over 250 families. At the top of the municipality was the chairman elected for three years and the municipal council, consisting of 4-12 members, elected by the people for three years. Municipality was homonym with the city and other settlements did not get involved in it, especially the villages. "Village "was the initial unit of local administration, governed by the headman, who was elected by the general meeting of the village and was in direct contact with the municipality. The village had a chief alderman consisting of 3-5 persons. Headman was responsible for implementation of laws and ordinances, and was interested in the social life of the village. The unit "Municipality" was unified with the "province". This unit includes several villages with the tradition of customary and social relations, with the ease of communication, and economic development opportunities. The mayor lead the commune assisted by the secretary and by the municipal council composed of aldermen. "Subprefecture "was the third link in the local administration. The sub prefecture was headed by the deputy prefect appointed by the mayor, his deputy and the secretary of the subprefecture. The unit was also composed of the order body, the Civil Registrar etc. Sub-prefecture performed executive power functions and was controlled by the prefecture and court inspector for the local government. "Prefecture" was the largest unit of local administration. Prefecture and sub-prefecture only exercised executive powers. At the top of the prefecture was "the prefect" who was assisted in his work by the deputy prefect and the secretary. Prefecture lacked elected bodies, but "the administrative council" was in function, consisting of the heads of administrative offices and several persons elected by the people every two years.

\section{Morphology of Local Government in 1945-1992}

After the end of World War II, until the mid of 1946, 10 prefectures and 61 sub-prefectures existed, but the commune and the municipality were abolished. With this local organization the census was conducted in September 1945, for the election of December 1945. By Law no. 284, dated August 22, 1946, the new administrative division was approved, which retained 10 prefectures and 39 sub-prefectures. With the new administrative division in 1947 the locality got wide use. The country was divided into 10 prefectures, into districts and localities, villages and towns. By Law no. 1707, in 1953 the new administrative division took place, where the largest unit was the county. Albania has 10 regions, 49 districts and 30 localities. In 1954 there was the County of Berat, Dibra, Durres, Elbasan, Gjirokastra, Korça, Kukës, Shkodra, Vlora, Tirana (Law no. No 284, dated August 22, 1946). By Decree no. 2773 of July 1958 the new administrative division was made. The county was abolished and the district became the base unit. Albania was divided into 26 districts and the city of Tirana was a separate administrative unit. There were 203 localities and 2664 settlements. The structure was as follows: the district, the locality and the village/ city. Tirana city was divided into smaller administrative units called "neighborhoods" (Decree no. 2773, July 1958Administrative division continued until 1967, when by decree of the Presidium of the National Assembly "On elections of people's councils and people's courts" the term "united village" entered the administrative morphology, as a result of socialist agricultural cooperation. In 1968, Albania had 26 districts, 104 locations, 315 united villages, 2545 villages and 56 cities. The "neighborhoods" were organized in some cities. The people's council was the legislative body of the district and the executive committee with the sections, dealing with issues of executive power. The people's council performed the executive and legislative functions in the "united village" and in the "city neighborhoods". This administrative organization continued until 1990 when with the amendments made from time to time there were 26 districts, 539 united villages, 306 cities' neighborhoods, 57 cities and 2848 villages.

After the first multiparty elections of 31 March 1991, the pluralist temporary committees were established on the basis of election results by political consensus. By Decision of Council of Ministers no 269, dated 25.06.1992, it was passed to a new division of the district, municipality/commune. By Decision of Council of Ministers, based on the law no 7608, dated 22.09.1992, the largest local unit "the prefecture" joined the administrative division. The implementation of these decisions created the local morphology consisting of 12 prefectures, 36 districts and 357 communes and municipalities (Law no 7608, dated 22.9.1992). Based on the Constitution of 1998, on the sixth chapter, on Articles 108113 , the communes, the municipality and the county were established as the basic units of local government, (Constitution of the Republic of Albania, 1998, p.15).

\section{Conclusions}

- To enhance the image and control over the territory, in the north and south, the government attempted to make a territorial and administrative reorganization in August 1913, declaring the kaza of Vlora a Sanjak. The 
government also discussed that Tepelena and Kurvelesh join the Sanjak of Vlora. At the same time Kaza of Mallakaster was established, with boundaries between Vjosa river and Seman river, based in Selisht. It was discussed of establishing Kaza of Fier as well. Kaza of Berat, Skrapar of Lushnja left unestablished. Mehdi Frashëri was appointed prefect of Berat. Following the departure of the Greek forces in the south, the Sanjak of Korca and Gjirokastra would be reorganized. While Përmeti and Leskoviku would create a separate Sanjak and the seat of Sanjak of Gjirokastra would be in Saranda, as a counterweight to Corfu. Ismail Qemali proposed the establishment of Sanjak in the region of Lumë, in the Highlands of Gjakova and Dukagjin, as well as in Mirdita..

- The beginning of decentralization with the local government law in Albania dated on November 23, 1913, with the act called "Canon of the the Civil Administration of Albania". With the law on the administrative organization of Albania the administrative division of the Empire, including Sanjak and mytesarif, kaza and kajmekam had been terminated and, prefectures, sub-prefectures and provinces were established.

- The basic principle on which the morphology of local government would rely was the "centralization of authority in vertical line"'”.

- Ismail Qemali showed the idea of regional organization based on the Swiss model, by naming the local units as "cantons". This view was not accepted because it would deepen the disunity and the independence of leading could become a source of intrigue, showing since the beginning of the new state the political elite's inability to cooperate and establishing a model of successful governance.

- With the Organic Statute of Albania on April 15, 1914 in Vlora, Albania was divided into 7 Sanjaks with Kaza and provinces, just as in the Ottoman Empire, getting back in mentality and organization.

- The Government of lliaz Vrioni made the first law of administrative division with the Organic Law of the Municipality, approved on November 26, 1921. According to law, the city with over 250 families may be proclaimed municipality. With the declaration of the Republic on January 21, 1925 the administrative-territorial organization changed and the country was divided into 10 prefectures, in subprefectures and communes or provinces (districts) and municipalities in urban areas.

- In 1926 Albania had the following Prefectures: Prefecture of Berat, Prefecture of Dibra, Prefecture of Durrës, Prefecture of Elbasan, Prefecture of Gjirokastër, Prefecture of Korçë, Prefecture of Kosovo /Kukës-A.B, Prefecture of Shkodër, Prefecture of Vlorë, Prefecture of Tirana.

- The greatest achievements in the form of local organization and the results that followed this organization were made during the period of the Albanian monarchy. According to administrative organization in 1934, the country was divided into 10 prefectures, 30 subprefectures, 160 communes and 2.551 settlements. By this division "the province" was abolished and "the commune" joined. In the organization of 1937 the vertical pyramid was maintained, but the term "district", "commune" and "municipality" was used in the names. This administrative organization was used up to the Italian fascist occupation, which in 1940 made a new administrative division, with 10 prefectures divided into 30 subprefectures.

- During the dictatorship, the administrative division was more of a formal character, because in reality, the government had a strong centralizing spirit.

- In 1992 Albania had 12 prefectures, 36 districts and 357 communes and municipalities. Today, with the changes following the new territorial reform, Albania has only 61 municipalities and 12 counties and no commune. Actually, local government is not administered by municipalities, communes and counties but only by municipalities. This has caused the need for these changes in authorities and competences to be reflected in the Constitution as well, through appropriate amendments.

- Administrative territorial divisions in Albania are not performed according to professional studies, but due to decisions and poor political accounts of the parties. This has brought significant consequences of the lack of social and economic development at levels comparable to surrounding countries.

\section{References}

Irakli Koçollari, Ali Pasha and Albania in the British Archives, Tirana: Iceberg 2013, p. 160-167. Referring to Ars, L. Grigori, I Allvania qe Ipiros sta teli tu XVIII qe stis arqes tu XIX eona Gutenberg, Athina 1994.

I. Koçollari, Standard, dated December 1, 2012, referred to Memories of Meternik, Vol. III, Paris 1881, p. 535-536.

Dritan Egro, "Some new data on the beginnings of Albanian nationalism" in historical studies, no. 3-4, Tirana, 2010, p. 12

The history of Albanian People, Vol. I The Academy of Sciences of Albania, Tirana: Toena, 2002, p. 145, f.172.

Albanian League of Prizren in Ottoman Documents, 1878-1881, Academy of Sciences of Albania, Institute of History, Tirana, 1978, p. 
100; Koço Nova, The development of the judicial organization in Albania ..., p. 58-59

Nuray Bozbora, Albania \& Albanian nationalism in the Ottoman Empire, Tirana, Dituria, 2002, p. 181

The history of Albanian People, Vol. The Academy of Sciences of Albania, Tirana: Toena, 2002, p f.220.

$\mathrm{AlH}, \mathrm{Vj}-22-32-6234$

AlH, Vj-22-32-6234, The letter of the Ministry of Foreign Affairs and Austria-Hungary no. 12087, dated August 15, 1912; "Freedom of Albania", no.54, Sofia, 25 th of August 1912, Count Berthold Project sent the Austro-Hungarian Embassy in Sofia,, No. 70, dated August 13, 1912

AlH, Vj-22-32-6234, Report of the Austro-Hungarian ambassador from Jeni Koj No.72 A-H, dated August 25, 1912, sent to Ministry of Foreign Affairs in Vienna

Ramiz Abdyli, the Albanian National Movement 1911-1912, Pristina, 2004, p. 408

"Drita" No. 98, Bitola, dated August 22, 1912, Isa Buletinasi 2

AQSH, F. 245, D.1, f. 25; Ismail Qemali Summary of documents..., p 280;

HHSt.A.PA. në AlH, Vj. 23-27-2786, Notification of Von Rudnei to Berchthold, Durres, dated June 7, 1913.

Aleks Luarasi, Legal acts for the History of State and Law in Albania, Tirana: LUARASI, 1999, p. 19-20-28-30

British Documents ..., V. II, p. 366-369, 41,75,77,78 minutes of the session 41,75,77,78; HHSt. A.PA.A në AlH, Vj.24-41-4138, Notification of Albanian delegate ad interim, in ICC, Mehmet Konica, to the chairman of the ICC.

British documents ...., V. II, doc. 2, attached to no.54, pp. 347-366; Organic Statute of Albania project; A.Luarasi, legal acts ..., p. 1-140. Law no. 284, dated August 22, 1946, published in the Official Journal.

Decree no. 2773, July 1958

Law no. 7608, dated 22.09.1992; Council of Ministers no. 269, dated 25.06.1992.

The Constitution of the Republic of Albania, 1998, p.15 